Review article

\title{
SERBIAN AGRICULTURE LOANS WITH THE AIM OF IMPROVING THE CURRENT SITUATION ${ }^{1}$
}

\author{
Vera Zelenović ${ }^{2}$, Željko Vojinovićs ${ }^{3}$, Drago Cvijanovićc ${ }^{4}$
}

\begin{abstract}
Summary
Agriculture is characterized by a number of specificities (seasonal and organic character, high risks of the production cycle, slow turnover of capital, inability to specialize production and low capacity utilization), due to which it is more demanding in terms of financing than other economic activities. Considering that the agraculture is one of the most important branches of the economy, which even in such difficult conditions and circumstances still yields profits, the subject of this work is to discuss the conditions of financing both by the state and by commercial banks, without which it is almost impossible to imagine the process of agricultural production. The aim of the paper is to point out the importance of stable and continuous financing of agriculture. Unfortunately, interest rate subsidy programs do not include consultations with the financial sector when programs are designed, and as a result, the way in which the programs are built does not motivate banks to increase lending to the agriculture sector. Farms need constant financial support because of the need to invest in production all at once and at a large scale, in accordance with the nature of production, the long retention period of the assets involved, ie the low turnover of the invested funds, and the low profit that the primary agricultural production generates makes it impossible to create own accumulation, or own sources of financing.
\end{abstract}

Key words: agriculture, financing, subsidies, credit.

JEL: $Q 18, Q 28, Q 48$

1 Paper is a part of research within the project no. 46006 III - Sustainable agriculture and rural development in the function of accomplishing strategic objectives of the Republic of Serbia in the Danube region, financed by the Ministry of Education, Science and Technological Development of the Republic of Serbia.

2 Vera Zelenović Ph.D., Professor, University Novi Sad, Faculty of Economics Subotica, Segedinski put no. 9-11, Subotica, Serbia, Phone +381 24628 164, E-mail:vera.zelenovic@ef.uns.ac.rs.

3 ŽeljkoVojinović Ph.D., Assistant Professor, University Novi Sad, Faculty of Economics Subotica, Segedinski put no. 9-11, Subotica, Serbia, Phone +381 24628 030, E-mail: zeljko.vojinovic@ef.uns.ac.rs,

4 Drago Cvijanović, Ph.D., Full Professor University Kragujevac, Faculty of Hotel Managementand Tourism, Vrnjačka Banja, Vojvodjanska street no 5A, Serbia, Phone +381 63295 111, E - mail:dvcmmv@gmail.com

EP 2018 (65) 1 (323-336) 


\section{Introduction}

Agriculture as an economic branch has great economic and social significance in the Republic of Serbia. It is characterized by a large number of organizational characteristics, which primarily arise from the use of natural conditions and the biological character of agricultural production. The planned production growth is based on rational production on already existing production areas and on the increase of yields, ie on the implementation of a series of measures of more efficient economy. Agriculture, and especially agricultural production, is characterized by a number of specificities (seasonal and organic character, high risks of the production cycle, slow turnover of capital, inability to specialize production and low capacity utilization), which in terms of financing is more demanding compared to other economic activities. These specifics condition that in agriculture there is a need to engage significant financial resources in the short term, which remain in the production process for a long time, and there is also a discrepancy between the time of investment in the valorization of production. Whether viewed in the narrow sense, as primary agricultural production, or in a wider sense as multifunctional agriculture, agriculture is "privileged" and has financial support in market-developed economies (Madžar, 2014).

Primary agricultural production, in the period after the breakup of the former SFRY, operates in extremely unstable, unpredictable and unfavorable conditions and is characterized by an unchanged production structure in, above all, capital-intensive production. All this occurs as a result of insufficiently effective measures of RS agricultural policy (Gulan, 2013).

On the other hand, the agriculture of Serbia and other countries in transition is characterized by a chronic lack of investment capital necessary for the development and structural adjustment of the domestic agricultural industry to a successful market economy (Vasiljević, 2017).

Agricultural policy is a part of the economic policy of a national economy or wider integration that focuses on directing the development of agriculture and its directly related activities and on various bases. Observed in the broadest sense, agrarian policy can be defined as the program of directing the development of agriculture within the already chosen model of development as a whole. The subject of agrarian policy is the entire vertical of agro-industrial production, which includes (Stankovic, 2012):

- production of agricultural inputs,

- production of primary agricultural products,

- production of agricultural products - food products,

- including traffic,

- final consumption and population nutrition policy.

Serbia has very favorable natural conditions (land and climate) for various agricultural production (both herbal and cattle), experienced producers, top experts and scientists. In the structure of the created value of agricultural production, $70 \%$ is from plant 
production, and 30\% from livestock production. For comparison, in the EU, $70 \%$ of the value in agriculture is from cattle breeding and 30\% from plant production. Agriculture and food industry in the creation of a social product of the country (GDP) participate with a share of around 11.9\% (http://www.pks.rs/PrivredaSrbije.aspx?id=13\&p=2\&)

\section{Methodology}

The subject of research in this paper is the presentation of the current situation in agriculture, from the aspect of financing agriculture both by the state and by commercial banks. The aim of the paper is to point out the importance of stable and continuous financing of agriculture, which should be in the function of its further development. During the research, written primary sources of data were used and analyzed, through analysis of content and using the statistical method.

\section{Current situation in agriculture}

The area of agricultural production is a very specific area of the entire economy of the Republic of Serbia. In the Republic of Serbia, agriculture significantly contributes to the creation of total value, and this is considerably more than is the case in many countries. Also, agricultural production directly and indirectly engages a large part of the total workforce of the country. It directly provides the basic source of income for all persons engaged in agricultural production activities.

Looking at the socio-economic structure of farms according to the income sources of their members, it indicates that in Serbia 326,015 family farms (52\% of the total number) have no other income except agriculture. In addition, it indirectly ensures livelihoods for persons engaged in production and transport processes that do not take place exclusively in the sphere of agriculture but for the purpose of its support (production of artificial fertilizers, agricultural machinery, packaging equipment and transport of agricultural products). Apart from this, agriculture is expected to be a motor for the development of rural areas of the country and thus contribute to the reduction of rising regional disparities (Bogdanov, Babović, 2014).

Frequent changes in the agrarian policy of the country, accompanied by insufficient budgetary allocations for the promotion of agriculture and rural development, have made it impossible to use the potential of agriculture in a higher degree. Structural reforms of the sector have not been completed and the business climate for dealing with agriculture has not been improved to the level that would make this area attractive for investment. From the aspect of creating an adequate environment for business in agriculture in the coming period, the implementation and monitoring of the national agricultural policy, which will be stable, predictable and consistent over the long term, is needed, which was not the case so far. Only in this way can the agricultural-food production sector be provided through the necessary basis for long-term planning of production processes, which are very often perennial (Bogdanov, Babović, 2014). 
Very important for the successful transformation of this sector of the economy is the successful completion of the privatization process in the field of agriculture. Still, significant resources in the field of agriculture are engaged in a way that does not lead to the maximization of the use of very favorable land, but also of objects within the entities in which the issue of ownership is not defined. The liberation of this potential, through the transformation of property to more productive users from the existing ones, would significantly improve the performance of the agriculture of the country and contribute to the creation of a higher total value (Bogdanov, Babović, 2014).

Table 1. Production of agricultural goods and services at producer prices of the current year, Republic of Serbia (million RSD)

\begin{tabular}{|c|c|c|c|c|c|c|c|c|}
\hline & $\mathbf{2 0 0 7}$ & $\mathbf{2 0 0 8}$ & $\mathbf{2 0 0 9}$ & $\mathbf{2 0 1 0}$ & $\mathbf{2 0 1 1}$ & $\mathbf{2 0 1 2}$ & $\mathbf{2 0 1 3}$ & $\mathbf{2 0 1 4}$ \\
\hline $\begin{array}{c}\text { Production of } \\
\text { agricultural goods and } \\
\text { services }\end{array}$ & 330.174 & 417.832 & 407.851 & 466.811 & 519.960 & 502.684 & 544.442 & 569.387 \\
\hline $\begin{array}{c}\text { Production of } \\
\text { agricultural goods }\end{array}$ & 320.756 & 407.406 & 396.221 & 455.753 & 509.125 & 491.597 & 531.469 & 554.639 \\
\hline Plant production & 217.274 & 278.825 & 265.101 & 328.981 & 359.103 & 324.451 & 358.223 & 376.110 \\
\hline Livestock production & 103.482 & 128.581 & 131.119 & 126.772 & 150.022 & 167.146 & 173.246 & 178.528 \\
\hline Agricultural services & 9.418 & 10.426 & 11.630 & 11.058 & 10.834 & 11.087 & 12.973 & 14.748 \\
\hline
\end{tabular}

Source: Statistical Office of the Republic of Serbia, (2016) Statistical Yearbook of the Republic of Serbia, Belgrade, p. 228

Table 1 contains data on the production of agricultural goods and services in Serbia in the period from 2007 to 2014. The value of agricultural production in Serbia in the analyzed period has a tendency of growth, except in 2009 and 2012 when it fell by about $3.5 \%$ in comparison with the previous years. Serbia was hit by extreme drought in 2012, the second most severe year in the series since 1951, (www.hidmet. gov.rs/podaci/meteorologija/latin/2012.pdf), with the consequences of which were major shortcomings in the crop. Although in the mentioned years a slight decline in agricultural production was recorded, it can be concluded that in the analyzed period average production growth was around $72.5 \%$.

Serbia's agrarian foreign trade, accounting for a quarter of total exports, recorded a tendency for growth in agricultural production surpluses. It represents a serious potential for growth and development, balance sheet balancing and ensuring the stabilization of macroeconomic indicators. Agriculture with the food sector participates in the total exports of the Republic of Serbia from $23 \%$ in recent years, which can be seen in the following table. 
Table 2. Participation of the agricultural food sector in the trade balance of the Republic of Serbia in the period from 2009 to 2013

\begin{tabular}{|l|c|c|c|c|c|}
\hline & $\mathbf{2 0 0 9}$ & $\mathbf{2 0 1 0}$ & $\mathbf{2 0 1 1}$ & $\mathbf{2 0 1 2}$ & $\mathbf{2 0 1 3}$ \\
\hline $\begin{array}{l}\text { Participation of agriculture in total exports of Serbia } \\
\text { in } \%\end{array}$ & 23,4 & 23 & 23,2 & 24,1 & 23,4 \\
\hline $\begin{array}{l}\text { Participation of agriculture in total imports of Serbia } \\
\text { in } \%\end{array}$ & 8,7 & 6,6 & 7,4 & 8,3 & 8,2 \\
\hline Coverage of export with import in \% & 140,8 & 207,6 & 185,8 & 147,5 & 178,8 \\
\hline
\end{tabular}

Source: Strategy of Agriculture and Rural Development of the Republic of Serbia for the period 2014-2024. (2014) "Sl. glasnik RS “, no. 85/2014, Ministry of Agriculture, Belgrade, p. 8

World trade in agro-food products includes high-quality and safe products in terms of consumer health, as well as food offer at affordable prices for consumers. The significance of the agricultural sector for Serbia is very large, and in Figure 4 it shows the movement of exports of agro-food products.

Graph 1. Movement of the total export of agro-food products of Rebulika of Serbia

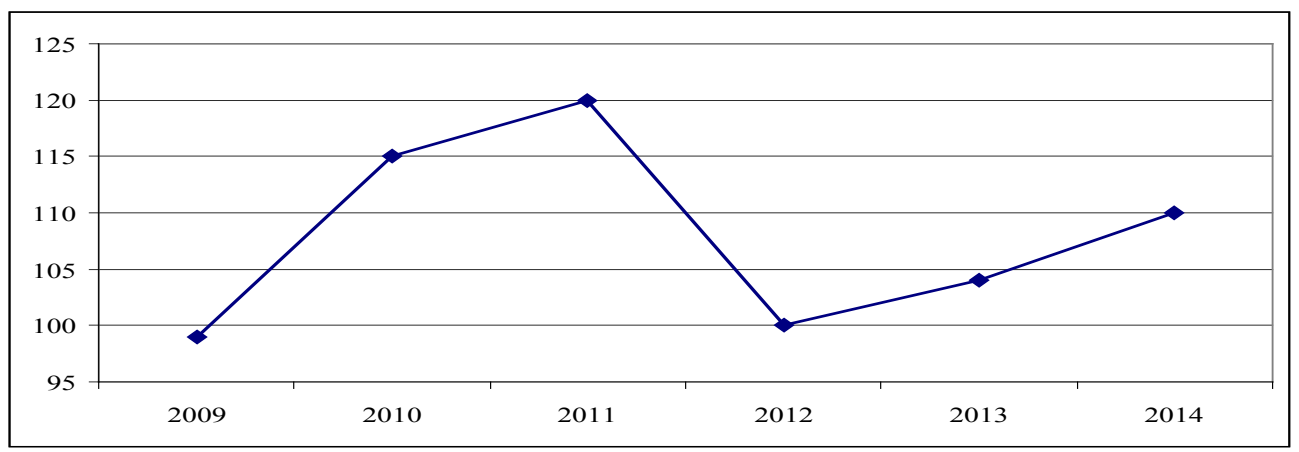

Source: Statistical Office of the Republic of Serbia

In 2009, there was a significant drop in exports as a result of the economic crisis, while in 2012 the export was also significantly lower than in the observed years due to weather conditions.

In line with the trend of organic farming in recent years, Serbia has recorded an exceptional growth (424\%) of the value of exports of organic products. In 2015, the value of export of organic production amounted to $€ 19.6$ million, of which $70.4 \%$ of exports for the final destination had the EU, where the largest importer is Germany (Simić, 2017). 
Graph 2. The value of exports of organic products from Serbia (in million $€$ )

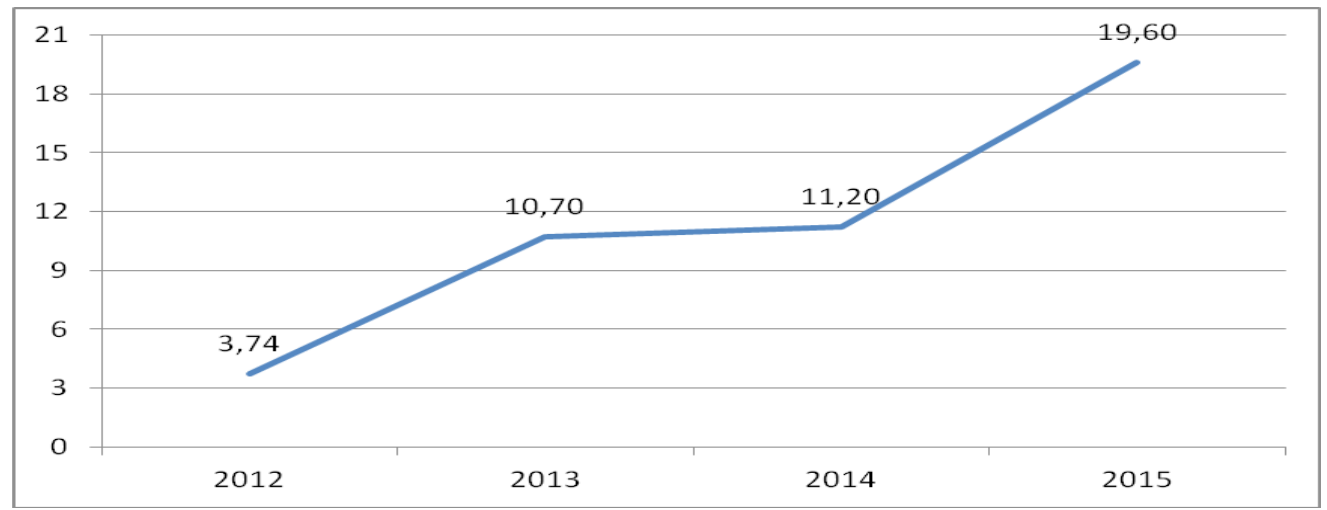

Source: Customs Administration

The export structure of Serbia is characterized by export of agricultural products and products of lower level of finalization. The future growth of export of agricultural products should include stable and sustainable growth in production, product range and product quality. It is necessary to adjust the export structure to demand, to affirm the internal business economics and to improve competitiveness in order to maximize the comparative advantages in production and export. All export products have priority in development and agrarian policy. In order to realize the strategic definition, besides the prominent, it is necessary to operate operatively (Božić, Bogdanov, Ševarlić, 2011):

- To improve the poor assortment of food products by developing a high-quality quality assortment;

- Increase the use of production capacity in poultry, increase the existing export assortment and introduce new lines and a set of new products to increase economy, competitiveness and exports;

- To increase the export of quality certified products from organic production to the markets of developed countries;

- Establish integral business relations between manufacturers, processors and traffic, strict compliance with quality standards, labeling, product design, packaging and packaging of products;

- Establish a business organization of producers in cooperatives or collectives and further promote shareholder engagement with processing and trade;

- Financial support and stimulation of production and products for export to the regional and world market. Our mission abroad is to attract investments and increase exports from the Serbian economy and agriculture.

\section{Financing agriculture}

Serbian agriculture has been producing relatively limited effects for years. One of the important factors is the financial system's incompetence to its needs, despite the fact that there are a significant number of different sources of funding. This contributes to the 
availability of financial resources for farmers and agricultural SMEs that can be judged to be least adequate in comparison with other sectors (Pejanović, Njegovan, 2009).

Despite its economic and political importance, the Serbian agricultural sector continues to hamper a number of restrictions that limit its full potential. In addition to obsolete production technologies and machines, the lack of adequate infrastructure (eg storage / cooling) and inadequate irrigation and drainage systems, the lack of sufficient agricultural finance compared to other sectors, many observers consider as one of the main obstacles to growth and sector development ( Njegovan, Filipovic, Pejanovic, 2009).

Agribusiness faces significant restrictions on access to finance due to high risk and lack of market understanding by banks (Njegovan, 2005).

Table 3. Budget of the Ministry of Agriculture for the period from 2001 to 2014

\begin{tabular}{|c|c|c|c|c|c|c|}
\hline \multirow{3}{*}{ Year } & \multirow{3}{*}{$\begin{array}{l}\text { Official } \\
\text { Gazette } \\
\text { Republic } \\
\text { of Serbia }\end{array}$} & \multirow{3}{*}{$\begin{array}{l}\text { Total budget } \\
\text { (funds from the } \\
\text { budget, total } \\
\text { revenues and } \\
\text { expenditures) }\end{array}$} & \multicolumn{4}{|c|}{ Budget of the Ministry of Agriculture } \\
\hline & & & \multicolumn{2}{|l|}{ Budget funds } & \multicolumn{2}{|l|}{ Total funds } \\
\hline & & & Amount & $\begin{array}{l}\% \text { from } \\
\text { the } \\
\text { national }\end{array}$ & Amount & $\begin{array}{l}\text { \% from } \\
\text { the } \\
\text { national }\end{array}$ \\
\hline 2001 & $21 / 2001$ & 129.369 .200 .000 & 5.256 .000 .000 & $4,06 \%$ & & \\
\hline 2002 & \begin{tabular}{|l|}
$74 / 2001$ \\
$86 / 2002$ \\
\end{tabular} & 217.379 .629 .540 & 5.406 .925 .000 & $2,49 \%$ & 5.626 .925 .000 & $2,59 \%$ \\
\hline 2003 & $\begin{array}{l}86 / 2002 \\
35 / 2003\end{array}$ & 318.691 .919 .000 & 9.058 .777 .000 & $2,84 \%$ & 10.990 .102 .000 & $3,45 \%$ \\
\hline 2004 & \begin{tabular}{|l|}
$33 / 2004$ \\
$115 / 2004$ \\
\end{tabular} & 362.045 .252 .000 & 18.059 .553 .000 & $4,99 \%$ & 20.144 .553 .000 & $5,56 \%$ \\
\hline 2005 & \begin{tabular}{|l|}
$127 / 2004$ \\
$66 / 2005$ \\
\end{tabular} & 400.767 .778 .000 & 16.269 .962 .000 & $4,06 \%$ & 18.983 .562 .000 & $4,74 \%$ \\
\hline 2006 & $\begin{array}{l}106 / 2005, \\
108 / 2005 \\
\end{array}$ & 505.820 .602 .000 & 23.593 .481 .000 & $4,66 \%$ & 27.543 .882 .020 & $5,45 \%$ \\
\hline 2007 & $58 / 2007$ & 595.517 .786 .100 & 21.410 .029 .000 & $3,60 \%$ & 26.095 .751 .714 & $4,38 \%$ \\
\hline 2008 & \begin{tabular}{|l|}
$123 / 2007$ \\
$102 / 2008$ \\
\end{tabular} & 695.959 .075 .793 & 27.634 .337 .342 & $3,97 \%$ & 32.895 .369 .077 & $4,73 \%$ \\
\hline 2009 & $\begin{array}{l}120 / 2008, \\
31 / 2009 \\
\end{array}$ & 719.854 .143 .000 & 16.964 .071 .000 & $2,22 \%$ & 26.690 .456 .000 & $3,71 \%$ \\
\hline 2010 & $\begin{array}{l}107 / 2009, \\
91 / 2010 \\
\end{array}$ & 825.884 .941 .052 & 20.572 .438 .000 & $2,49 \%$ & 31.577 .881 .000 & $3,82 \%$ \\
\hline 2011 & \begin{tabular}{|l|}
$101 / 2010$ \\
$78 / 2011$ \\
\end{tabular} & 922.232 .037 .407 & 22.533 .211 .000 & $2,44 \%$ & 33.676 .039 .091 & $3,65 \%$ \\
\hline 2012 & \begin{tabular}{|l|}
$101 / 2011$ \\
$93 / 2012$ \\
\end{tabular} & 1.018 .633 .424 .655 & 40.876 .729 .559 & $4,01 \%$ & 40.876 .729 .559 & $4,01 \%$ \\
\hline 2013 & $59 / 2013$ & 1.040 .014 .339 .000 & 44.699 .546 .000 & $4,30 \%$ & 44.699 .546 .000 & $4,30 \%$ \\
\hline 2014 & $116 / 2014$ & 1.110 .120 .984 .547 & 5.427 .166 .241 & $4,09 \%$ & 45.427 .166 .241 & $4,09 \%$ \\
\hline
\end{tabular}

Source: Law on the Budget of the Republic of Serbia for the relevant years 
In the previous period of 14 years, the amount of the agrarian budget, in terms of the amount of state subsidies defined for the promotion of agriculture and rural development, varied considerably. The total amount of the agrarian budget ranged from $2.22 \%$ of the national budget (2009) to 4.99\% (2004). In absolute terms, the agrarian budget reaches its maximum in 2014 (45.4 billion dinars) and the minimum in 2001 (5.5 billion dinars).

Bearing in mind that the own revenues of the Ministry of Agriculture, which are acquired from different legal bases, are passed on to beneficiaries (entities of agribusiness) through various agrarian / rural policies, the analysis also includes these funds as part of the agrarian budget, that is, the total budgetary funds spent to encourage the development of agriculture.

Serbian agriculture could face very difficult challenges on the path of European integration, but that sector at the same time probably will benefit greatly from membership in the European Union; if Serbia is a member of the European Union, it would receive about 1.6 billion euros a year from agricultural and rural development funds, which in 2010 totaled 55 billion euros. Serbia will have to adapt to EU regulations and standards on the road to EU membership, which will significantly alter the situation in Serbian agriculture.(http://euinfo.rs/files/Publikacije-srp/31_Poljopricreda_i_EU.pdf).

\section{Subsidized loans in agriculture}

Banks that focus on lending to agribusiness indicate uncertainty in planning, inconsistency in Serbian agricultural policy, poorly designed interest rate, subsidy programs, and lack of borrowers as the main obstacle to increasing lending. The relevant ministry has a high turnover of key people and changes its priorities very often. This leads to unpredictability of cash flows in agribusiness and reduces the creditworthiness of potential clients. Interest rate subsidies programs do not include financial sector consultations when programs are designed, and as a result, the way in which the programs are built do not motivate banks to increase lending to the sector. Moreover, subsidized loans negatively affect the credit market sending wrong signals to agribusinesses about the costs of financing. Lack of effective Cooperative Law and non-efficient agribusiness associations aggravate the ability of banks, offer products that do not rely on the creditworthiness of individual borrowers (Jolović, Njegovan, Čavlin, 2014).

The state provided subsidies in terms of finding the favourable financial resources in form of part of interest rate or insurance premium. The bank and insurance companies' representatives have assessed that this program will significantly contribute to the agricultural production improvement, in individual holdings, and the interest for this has been growing from year to year. The contracts are concluded with the following banks (Vojinović, Zelenović, Cvijanović, 2017):

$>$ Commercial Bank

$>$ ProCredit Bank

$>$ Credit Agricole Bank 
$>$ Hypo AlpeAdria Bank

$>$ BancaIntesa

$>$ Sberbank

$>$ AIK Bank

$>$ NLB Bank

$>$ Unicredit Bank

$>$ OTP Bank

On the other hand, the contracts were concluded also with insurance underwriters :

$>$ Dunav insurance,

$>$ Delta Generali insurance,

$>$ DDOR Novi Sad,

$>$ Triglav insurance,

$>$ Globos insurance.

Insurance of agriculture is voluntary in Serbia. General conditions of crop insurance, except husbandry, predict contracting franchises in the range from $5 \%$ to $50 \%$. Farmers pay a lower premium through the introduction of franchisees but when damage occurs they are not satisfied with it, because they expect to be paid the total amount of damage they have suffered. Since the damage to fruit compared to secured areas are by far the largest, insurance companies insist on franchising these crops, usually $10-20 \%$ (Birovljev, Vojinović, Balaban, 2015).

Subsidized loans from the Ministry of Agriculture, Forestry and Water Management are intended for farmers in cooperation with commercial banks that approve loans while the Ministry of Agriculture subsidizes interest on these loans. State credit support is a kind of incentive to facilitate access to credit for agricultural holdings 5 .

Table 4. Conditions under which subsidized loan in agriculture is granted

\begin{tabular}{|l|l|}
\hline Purpose & $\begin{array}{l}\text { In the development of animal husbandry, in the development of agriculture, } \\
\text { fruit growing, viticulture, horticulture and flower growing, investment } \\
\text { in new agricultural machinery and equipment, the supply of animal feed, } \\
\text { investment in certain types of machinery and equipment used in plant } \\
\text { agricultural production. }\end{array}$ \\
\hline Currency & RSD without currency clause \\
\hline $\begin{array}{l}\text { Nominal } \\
\text { interest rate }\end{array}$ & Fixed interest rate of 3\% per annum \\
\hline $\begin{array}{l}\text { Deadline for } \\
\text { repayment of } \\
\text { the loan }\end{array}$ & From 1 to 3 years \\
\hline
\end{tabular}

5 Banks that grant credits to farmers in Serbia do not publicly announce how much funds have been approved on this issue

EP 2018 (65) 1 (323-336) 


\begin{tabular}{|l|l|}
\hline Grace period & From one year \\
\hline $\begin{array}{l}\text { Loan } \\
\text { repayments }\end{array}$ & $\begin{array}{l}\text { Loans with a repayment term of up to three years are repaid in monthly, } \\
\text { quarterly, six-month and annual annuities, and loans repayable from three to } \\
\text { five years are repaid in six-month annuities. }\end{array}$ \\
\hline Loan amount & $\begin{array}{l}\text { Individual- the owner of a commercial family farm and entrepreneur can } \\
\text { exercise the right to credit support up to 6,000,000 dinars. A legal entity can } \\
\text { exercise the right to credit support provided that the total loan amount is up } \\
\text { to } 18,000,000 \text { dinars. }\end{array}$ \\
\hline
\end{tabular}

Source: $h t t p: / / s u b v e n c i j e . r s / k r e d i t i / s u b v e n c i o n i s a n i-k r e d i t i-m i n i s t a r s t v a-p o l j o p r i v r e d e / s u b v e-$ ncionisani-krediti-ministarstva-poljoprivredesumarstva-vodoprivredel 22.05.2017.

In the APV Development Fund, 8 credit lines have been opened for the development of economy, agriculture and local self-governments. The main objectives of the loan allocation are the provision of financial resources to support the development and improvement of the agricultural sector by increasing the level of technical equipment, increasing the volume, efficiency and intensification of agricultural production, increasing productivity, raising the level of competitiveness and protecting the environment as well as encouraging the joint participation of several holders of individual agricultural holdings in the realization of a joint investment in agriculture to improve the market position of individual farms. The right to participate in the competition is held by an individual - bearers of registered agricultural holdings in the territory of AP Vojvodina, who have active status of the household.

In addition, the Fund has made a major contribution in the last few years, cofinancing amounts up to $60 \%$ for investments in procurement of irrigation systems, procurement of anti-ship networks, construction of silo, refrigerators and other storage capacities. Also, the Guarantee Fund plays an important role in the agriculture of Vojvodina, which greatly facilitates the taking of loans for large investments.

Table 5. Conditions for granting long-term agricultural loans by DF APV

\begin{tabular}{|l|l|}
\hline Purpose & $\begin{array}{l}\text { Purchase of agricultural machinery for agricultural production (tractors, } \\
\text { combines and connecting machines), procurement of equipment for } \\
\text { agricultural production, procurement of quality breeding material in livestock } \\
\text { and breeding flocks, procurement of perennial fruit plants, grapevine and } \\
\text { other perennial plantations with equipping surface areas, procurement of anti- } \\
\text { ship network with backbone, procurement of equipment for protected area, } \\
\text { construction of wells and procurement of equipment and irrigation systems, } \\
\text { procurement of equipment for capacity increase and modernization of lines } \\
\text { for processing primary agricultural products, construction, adaptation and } \\
\text { equipping of storage capacities - cold storage and floor storage, construction } \\
\text { and adaptation buildings for livestock production in order to protect the } \\
\text { environment and fulfill the standards in the field of agricultural production. }\end{array}$ \\
\hline Currency & $\begin{array}{l}\text { Application of currency clause, middle exchange rate of euro on the day of } \\
\text { received payment or outgoing payment }\end{array}$ \\
\hline
\end{tabular}




\begin{tabular}{|c|c|}
\hline $\begin{array}{l}\text { Nominal interest } \\
\text { rate }\end{array}$ & $\begin{array}{l}2 \% \text { per annum for loans secured by a bank guarantee and } 3 \% \text { per annum for } \\
\text { loans secured by mortgages; The interest rate for credit beneficiaries who } \\
\text { perform their business activities in the territories of cities and municipalities } \\
\text { of APV classified in the third and fourth development groups is reduced } \\
\text { by one percentage point. Own participation: at least } 20 \% \text { of the estimated } \\
\text { investment value (excluding current assets). }\end{array}$ \\
\hline $\begin{array}{l}\text { Deadline for } \\
\text { repayment of } \\
\text { the loan }\end{array}$ & $\begin{array}{l}5 \text { years, except for the purchase of breeding flocks, bee hives and hives with } \\
\text { accompanying equipment when the return period is } 3 \text { years }\end{array}$ \\
\hline Grace period & $\begin{array}{l}\text { From one year, except for the financing of the purchase of quality breeding } \\
\text { material in livestock and for financing programs in the field of fruit and wine } \\
\text { growing and the establishment of other perennial plants, when the grace } \\
\text { period is } 24 \text { months. }\end{array}$ \\
\hline $\begin{array}{l}\text { Loan } \\
\text { repayments }\end{array}$ & $\begin{array}{l}\text { Annuities are calculated and paid quarterly. In the grace period, intercity } \\
\text { interest in the amount of the agreed interest rate is paid quarterly. }\end{array}$ \\
\hline Loan amount & From $300,000,00$ to $10,000,000,00$ dinars \\
\hline Securing loans & $\begin{array}{l}\text { Personal bills of the individual of the holder of the registered agricultural } \\
\text { holding. Guarantee of a commercial bank or mortgage - a pledge right of } \\
\text { first order or lower if the Fund is the only mortgage creditor on agricultural } \\
\text { land in favor of DF APV. Novi Sad, whose minimum ratio of the estimated } \\
\text { market value and the required loan is } 150 \% \text {, or a pledge on a newly-acquired } \\
\text { agricultural agricultural machine financed by loan funds. }\end{array}$ \\
\hline
\end{tabular}

Source: http://www.rfapv.rs/index-412.html

\section{Non-performing loans in agriculture}

The branches that handle troubled loans are the processing industry, trade, construction, education and real estate, agriculture and transport, hotels / restaurants.

Table 6. Gross NPL for companies by branches 2013-2016 (in billion RSD)

\begin{tabular}{|l|c|c|c|c|}
\hline & \multicolumn{4}{|c|}{ Years } \\
\hline Economic branches & 31.12 .2016$. & 31.12 .2015$. & 31.12 .2014$. & 31.12 .2013 \\
\hline Manufacturing industry & 60639 & 69086 & 79892 & 81986 \\
\hline Trade & 38151 & 58062 & 62013 & 63652 \\
\hline Construction & 24494 & 27770 & 36152 & 44276 \\
\hline Education and real estate & 21337 & 25799 & 29030 & 26110 \\
\hline Agriculture & 4067 & 6257 & 9852 & 9133 \\
\hline $\begin{array}{l}\text { Transport, hotels / restaurants, } \\
\text { communications }\end{array}$ & 8613 & 10906 & 10726 & 12440 \\
\hline
\end{tabular}

Source: Authors'view based on downloaded data https://www.nbs.rs/internet/latinica/55/55_4/ kvartalni_izvestaj_IV_16.pdf, str. 21 10.10.2017.

From Table 7 we can see that from year to year the gross amount of problem loans in all sectors is reduced, observing the period from 2013 to 2016 . Reduction can be 
attributed to active operations in the field of credit risk management and a greater focus on collecting receivables. The same situation is when the agriculture is in question, namely in the observed period, the NPL has a downward trend, except in 2014, which is partly the consequence of the large floods that had occurred in Serbia at the time. After 2014, NPL in agriculture records a credible rate of decline, which is evidence that the market is stabilizing, as there is often a chain reaction related to the stability and health of the economy.

\section{Conclusion}

Despite its economic and political importance, the Serbian agricultural sector continues to hamper a number of restrictions that limit its full potential. One of the key reasons for this is the incompetence of the financial system to its needs, despite the fact that there are a significant number of different sources of funding. This contributes to the availability of financial resources for farmers and agricultural SMEs which can be assessed as least adequate in comparison with other sectors. The next major problem of our agrarian sector is the insufficient consolidation of the estate, a large number of small plots scattered by different ataries of only one village, which leads to high production costs, loss of productivity and economy, which additionally complicates the situation when financing is in question. Experience has shown that reduced subsidies have drastically influenced the quality and quantity of agricultural production, as with reduced incentives, investments have also been reduced (fertilizers, hybrid seeds, spraying agents). The unfavorable conditions for financing the agrarian sector can lead to the collapse of a large number of small agricultural holdings, which will be forced to offer their possessions to foreign and domestic large-scale capital. Therefore, the role of the state in subsidized funding is extremely important, because commercial banks have exclusive interest in profits when it comes to credit placements. Farmers as individuals, most often put a mortgage on the land when taking loans, making them very attractive to banks. The state's influence is essential and necessary, and the financial resources that the state has at its disposal should be in the function of developing agricultural production, while the policy of their spending should be in the context of national interest.

\section{Literature}

1. Birovljev, J., Vojinović, Ž., Balaban, M., Potential of agricultural production and its impact on insurance premiums, Economics of Agriculture Vol.LXII, No 3 (575-898) 2015, Beograd

2. Bogdanov N., Babović M. (2014). Radna snaga i diverzifikacija prihoda na poljoprivrednim gazdinstvima u Srbiji - stanje i izazovi za politiku ruralnog razvoja, Zbornik radova: Primena podataka Popisa poljoprivrede 2012. u analizi stanja poljoprivrede i u planiranju agrarne politike u Republici Srbiji, Republički zavod za statistiku, Subotica, ISBN-978-8686-6161- 115-5, str. 262

3. Božić, D., Bogdanov, N., Ševarlić M. (2011) Ekonomika poljoprivrede, Poljoprivredni fakultet, Beograd, str. 59 
4. Gulan, B., “Kako pomoći farmerima”, Novi korak, 2013.

5. Jolović, A., Njegovan, Z., Čavlin, M., (2014.) "Financing of the agriculture in Serbia: state and prospects", Economics of Agriculture 1,

6. Madžar, L.,Značaj i izvozni potencijal privrede Republike Srbije sa posebnim osvrtom na stanje stočnog fonda, Škola biznisa, Broj 2/2014 UDC 631:339.5(497.11) str.124-140

7. Njegovan, Z., Filipović, M., Pejanović, R., (2009). "Privredni sistem, politika $i$ razvoj", Poljoprivredni fakultet, Novi Sad, 2009.

8. Njegovan, Z., "Risk analysis and Decission making process in agricultural enterprises of the CEEC", Industrija, Ekonomski institut, Beograd, 2005.

9. Pejanović, R., Njegovan, Z., (2009) .:"Aktuelni problemi poljoprivrede i sela Republike Srbije", Industrija, Ekonomski institut, Beograd.

10. Republički zavod za statistiku,(2016) Statistički godišnjak Republike Srbije, Beograd, str. 228

11. Simić, I. (2017) Organska poljoprivreda u Srbiji 2017, Nacionalno udruženje za razvoj organske proizvodnje Serbia organika, Beograd, str. 41

12. Stanković M. (2012) Agrarna politika Srbije i zajednička poljoprivredna politika, Škola biznisa, Broj 3/2012, UDC 338.43.02(497.11), 2012, str. 65

13. Službeni glasnik Republike Srbije , br. 85/2014 (2014) "Strategija poljoprivrede i ruralnog razvoja Republike Srbije za period 2014- 2024. godine" Ministarstvo poljoprivrede, Beograd, str. 8

14. Uprava carina, dostupno na www.upravacarina.rs

15. Vojinović Ž, Zelenović, V., Cvijanović, D., Program of state support to agricultural crediting, Economics of Agriculture Vol LXIV, N1 (1-404), 2017. Beograd

16. Vasiljević, Z., (2007). “Osnovni pravci reforme agrarne politike u Srbiji”, Naučna konferencija - Izazovi ekonomske politike Srbije u 2007. godini, Beograd, 2007

17. http://www.rfapv.rs/index-412.html

18. http://www.pks.rs/PrivredaSrbije.aspx?id=13\&p=2\&

19. http:/www.hidmet.gov.rs/podaci/meteorologija/latin/2012.pdf ( dostupno na dan 15.08.2017.)

20. http://euinfo.rs/files/Publikacije-srp/31_Poljopricreda_i_EU.pdf (dostupno na dan 10.10.2017

21. https://www.nbs.rs/

22. http://subvencije.rs/krediti/7854/

23. http://subvencije.rs/krediti/subvencionisani-krediti-ministarstva-poljoprivrede/ subvencionisani-krediti-ministarstva-poljoprivredesumarstva-vodoprivrede/ (dostupno na dan 22.05.2017.)

24. https://www.nbs.rs/internet/latinica/55/55_4/kvartalni_izvestaj_IV_16.pdf (dostupno na dan 10.10.2017.) 


\title{
KREDITIRANJE POLJOPRIVREDE SRBIJE SA CILJEM UNAPREĐENJA POSTOJEĆEG STANJA
}

\author{
Vera Zelenović ${ }^{6}$, Željko Vojinovič ${ }^{7}$, Drago Cvijanovic ${ }^{8}$
}

\begin{abstract}
Sažetak
Poljoprivredu karakteriše niz specifičnosti (sezonski i organski karakter, visoki rizici proizvodnog ciklusa, spor obrt kapitala, nemogućnost specijalizacije proizvodnje $i$ nizak stepen iskorišćenosti kapaciteta) zbog kojih je sa aspekta finansiranja zahtevnija u odnosu na druge privredne delatnosti.Obzirom da je agrar jedna od najvažnijih grana privrede, koja i u ovako teškim uslovima i okolnostima ipak donosi profit, predmet rada je razmotranje uslova finansiranja kako od strane države, tako i od strane komercijalnih banaka, bez kojih je skoro nemoguće zamisliti proces poljoprivredne proizvodnje. Cilj rada je da se ukaže na značaj stabilnog $i$ kontinuiranog finansiranja poljoprivrede. Nažalost, programi subvencioniranja kamatne stope ne uključuju konsultacije sa finansijskim sektorom kada su programi dizajnirani, i kao rezultat, način na koji su programi izgrađeni ne motivišu banke da povećaju kreditiranje u sektor poljoprivrede. Poljoprivredi je neophodna stalna finansijska podrška zbog potrebe da se sredstva ulože u proizvodnju odjednom i to u velikom obimu, u skladu sa prirodom proizvodnje, dugim periodom zadržavanja angažovanih sredstava, odnosno niskim obrtom uloženih sredstava, te niskim profitom koji ostvaruje primarna poljoprivredna proizvodnja, a koji onemogućava stvaranje sopstvene akumulacije, odnosno sopstvenih izvora finansiranja.
\end{abstract}

Ključne reči : poljoprivreda, finansiranje, subvencije, kredit

6 Vera Zelenović Ph.D., Professor, University Novi Sad, Economic faculty Subotica, Segedinski put no. 9-11, Subotica, Serbia, Phone +381 24628 164, E-mail:vera.zelenovic@ef.uns.ac.rs.

7 ŽeljkoVojinović Ph.D., Assistant Professor, University Novi Sad, Economic faculty Subotica, Segedinski put no. 9-11, Subotica, Serbia, Phone +381 24628 030, E-mail: zeljko.vojinovic@ef.uns.ac.rs,

8 Drago Cvijanović, Ph.D., Full Professor University in Kragujevac, Faculty of Hotel Managementand Tourism, Vrnjačka Banja, Republic of Serbia, Vojvodjanska street no 5A, 36210 VrnjačkaBanja, Serbia, Phone +381 63295 111, E - mail:dvcmmv@gmail.com 